DOI: 10.46340/eppd.2020.7.2.38

Ігор Мисловський

Київський національний університет імені Тараса Шевченка, Україна

ДЕТЕРМІНАНТИ СТЕРЕОТИПІЗАЦЇ̈

ФЕНОМЕНУ ТЕРОРИЗМУ

В ЖУРНАЛІСТСЬКОМУ СЕРЕДОВИЩ

\author{
Ihor Myslovskyi \\ ORCID ID: https://orcid.org/0000-0001-7122-8086 \\ Taras Shevchenko National University of Kyiv, Ukraine

\section{DETERMINANTS OF STEREOTYPING OF THE TERRORISM PHENOMENON AMONG JOURNALISTS}

The article analyzes the factors that determine stereotyping of the terrorism phenomenon among journalists. Defining of those determinants has been done by applying the methods of deep analysis, an in-depth interview of experts, and a mixed questionnaire of Ukrainian international editors. Interviewing over 30 journalists has made it possible to outline professional opinion on the causes of stereotypes about terrorism and to highlight the most popular ones of them. However, it should be underlined that the popularity of determinants does not correlate with their impact indicator. The author develops a new typology, which helps to systematize all those determinants into four different groups. Having conducted a statistical analysis, it is also found out which types of determinants journalists consider the most influential in shaping a distorted image of terrorism. The author assumes that the primary elimination of those determinants or their types will greatly enhance the fight against stereotypes of terrorism not only among journalists but also in the whole information space.

Keywords: terrorism, media, stereotypes, determinants, mass communication.

Вступ. Темі тероризму відведене помітне місце у медійному agenda setting. Витоки самого феномену дослідники беруть чи не з самої появи людства, відколи погрози застосувати насильство та наслідковий страх використовували як тактику в досягненні своїх цілей. За приклад беруть навіть біблійні історії про “Десять кар Єгипетських”, кожна з яких може слугувати прототипом сучасному терористичному акту із застосуванням зброї масового ураження ${ }^{1}$. Проте значне пожвавлення висвітлення тероризму та входження тематики до медійного порядку денного сталося після теракту 1972 р. під час Олімпійських ігор у Мюнхені, а вже після трагедії 9/11 та оголошення американським президентом Дж. Бушем війни з тероризмом журналісти серйозно зосередили свою увагу на діяльності терористів.

Разом $з$ тим постало нове завдання - професійно висвітлювати цю тему в ЗМІ. Чи справді напад невідомих на об'єкт є терористичним актом, чи це диверсія іноземного агресора в рамках гібридного наступу? Коли сепаратист є терористом, а коли справедливим борцем за свободу свого народу? Яким чином міграція та релігія пов'язані 3 тероризмом та чи є його першопричинами? Чому одні держави певне угруповання називають терористичним, а інші вбачають у ньому легітимного політичного актора? На ці й інші питання журналіст, який бодай раз взявся за тему тероризму, повинен мати відповіді або принаймні розуміння контроверсійності згаданих питань.

Тематичні напрацювання дослідників. Нинішні реалії журналістської діяльності дещо відрізняються від цієї теоретичної парадигми, і висвітленням тероризму займаються медійники широкого тематичного профілю. Брак фахових знань та викривлене зображення феномену в медіа нині активно досліджуються в між- та інтердисциплінарних дослідженнях на базі наук про соціальні комунікації і тероризм. Дедалі більше науковців присвячують свої праці медіастереотипам

\footnotetext{
${ }^{1}$ Цыганов, В.В. (2004). Медиа-терроризм. Терроризм и средства массовой информации. Киев: Ника-Центр.
} 
про тероризм, зокрема Дж. Терзіс, Дж. Шахін, Е. Баккер, Б. Гоффман, Б. Накос, Дж. П’яцца, А. Крюгер, Ї. Малечкова та інші. Про непропорційність медійної уваги до терактів, зображення спотвореної терористичної діяльності i непрофесійне висвітлення явища наголошують такі дослідники, як А. Шмід, Ф. Фуреді, В. Ліпкан, В. Циганов, Г. Почепцов, О. Свентицька тощо.

Проте варто зауважити, що медіа часто не цілеспрямовано і не свідомо поширюють стереотипи про тероризм - відбувається це безпосередньо через стереотипне бачення цього феномену самими журналістами. Стереотипізація явища тероризму в журналістському фаховому ${ }^{1}$ та студентському $^{2}$ середовищах України вже була частково підтверджена автором цієї статті, а також досліджувалися ризики і наслідки непрофесійного медійного висвітлення феномену ${ }^{3}$.

Розв'язання такої комплексної проблеми потребує не лише встановлення першоджерела поширення стереотипів (певних комунікаторів), але й розуміння причин виникнення і постійної циркуляції хибної інтерпретації феномену тероризму серед журналістів. Тому мета цієї статті встановити детермінанти стереотипізації феномену тероризму в журналістському середовищі.

Відповідно до поставленої мети можна виокремити наступні завдання: 1) визначити фактори, які обумовлюють появу стереотипів про тероризм у журналістів; 2) встановити, що, на думку журналістів, впливає на формування стереотипного бачення феномену тероризму; 3) розробити типологію проаналізованих детермінант; 4) з'ясувати, які типи детермінант журналісти вважають найбільш розповсюдженими.

Для виконання першого завдання використовувалися методи глибинного аналізу та експертного інтерв'ю (опитані три академіки-терорологи і три медіапрацівники). Друге завдання передбачало проведення експертного фокусованого опитування (веб-анкетування), а третє використання методу типології (систематизація). Статистичний, метод аналізу, синтезу і групування забезпечили реалізацію останнього завдання.

Обговорення і результати. Реалії сучасної практичної української та й здебільшого зарубіжної журналістики такі, що наявні ресурси не дозволяють забезпечити широке коло вузькопрофільних фахівців на медіаринку. Чи часто в українських редакціях можна побачити журналістів, які спеціалізуються суто на тематиці тероризму або мають освітні досягнення у сфері терорології? На жаль, відповідь буде негативною. Переважно такою темою займаються міжнародні редактори чи військові журналісти, а за відсутності останніх - рядові кореспонденти. Однак практику так званого "універсального журналіста" (не лише технологічно різностороннього, а й тематично) широко сповідують і за кордоном. У цілях економії власники ЗМІ зменшують кількість працівників у редакціях, надаючи перевагу тим репортерам, які можуть з однієї події написати і замітку для газети, i статтю для інтернет-порталу, а потім ще й підготувати репортаж для телеканалу, попередньо розповівши про цю подію у форматі “прямого включення”. Реалізація такого універсального журналізму призвела до того, що штат, наприклад, британських редакцій за останні три десятиліття зменшився у 8-9 разів, хоча прибутки компаній зросли учетверо ${ }^{4}$. Економічний приріст став можливий завдяки збільшенню навантаження на працівників, які уникли скорочення. Однак через те, що їм доводиться готувати значно більше матеріалів, унеможливлюється пильна перевірка фактів і джерел інформації.

Щоправда, деякі світові поважні медіа мають спеціалізованих журналістів. Наприклад, Пітер Тейлор кілька десятиліть своєї журналістської кар'єри на ВВС присвятив висвітленню діяльності IPA та “Аль-Каїди", про що розповів у своїй книзі "Розмови з терористами”. Британець здобув чимало нагород за документалістику й отримав пожиттєву королівську відзнаку від телевізійної спільноти за вклад у журналістику. Але історія Тейлора швидше виняток, ніж реалії нинішніх редакцій, де завдання висвітлити теракт може отримати будь-хто із працівників.

\footnotetext{
${ }^{1}$ Мисловський, I.В. (2019). Міжкультурна комунікація у висвітленні тероризму: стереотипне бачення феномену українськими журналістами. Соціальні комунікаиї̈: фундаментальні парадигми розвитку: матеріали Міжнародної науково-практичної конференції (4-5 жовтня 2019 р., м. Київ), 1, 83-87.

${ }^{2}$ Мисловський, I.В. (2019). Бачення теми тероризму студентами-журналістами: сприйняття, розуміння та причини феномену. Сучасні перспективи розвитку науки: матеріали III Міжнародної науково-практичної конференції (10-11 вересня 2019., м. Київ), 1, 48-50.

${ }^{3}$ Мисловський, I.В. (2017). Ризики та наслідки непрофесійної діяльності журналістів у висвітленні теми тероризму. Страхогенерувальний потенціал новин. Медіаконтент: види, форми подачі та особливості сприйняття: матеріали Всеукраїнської науково-практичної конференції (4 квітня 2017 р., м. Київ), 1, $243-247$. ${ }^{4}$ Дейвіс, Н. (2011). Новини пласкої Землі. Київ: Темпора.

5 Тейлор, П. (2014). Розмови з терористами. Моя подорож від IРА до Аль-Каїди. Київ: Темпора.
} 
O. Мишкіна, яка працювала міжнародним редактором на трьох українських загальнонаціональних телеканалах (“NewsOne”, "Прямий”, “1+1"), розповіла нам, що висвітлення тероризму за межами України входило до їі обов'язків, хоча особисто вона не спеціалізується на тематиці, а під час навчання в університеті (Інститут журналістики Київського національного університету ім. Т. Шевченка) тероризм як феномен не вивчався. На її думку, це негативно впливає на якість матеріалів, оскільки у цьому випадку кореспонденти часто обмежуються короткими повідомленнями з інформаційних агентств, не з'ясовуючи мотиви та політичний контекст діяльності терористів навіть для самих себе. Журналістка зауважила, що нерідко бачила, як її колеги з інших відділів через брак знань в геополітиці перетворювали новину про тероризм у поверхневе страхогенерувальне інформаційне повідомлення, у якому терористів зображали як божевільних людей, а їхні атаки - як невідворотне лихо для простих громадян. При цьому, за словами О. Мишкіної, такий образ феномену справді вкорінився у журналістському середовищі, оскільки нині професія тяжіє до швидкого висвітлення подій, а не їхнього пояснення.

Поверхневе висвітлення тероризму журналістами продиктоване і природною складністю феномену. Стереотипи служать для спрощення розуміння складних об'єктів дійсності, до яких можемо зарахувати тероризм. За час існування явища людство так і не змогло дійти згоди щодо єдиного міжнародного терміну “тероризм”. Індійський дослідник Е. Туагі підрахував, що лише за період 1936-1986 рр. напрацьовано понад 115 визначень тероризму, з яких жодне не отримало міжнародного схвалення ${ }^{1}$. 31963 р. в межах ООН світова спільнота розробила 19 міжнародних угод, які націлені на запобігання терористичних атак. Проте досі дипломатам і працівникам всесвітньої організації, зокрема профільного Комітету з міжнародного тероризму та Цільової групи з реалізації контртерористичних заходів, не вдалося затвердити на офіційному рівні загальновизнане поняття “тероризму".

А. Шмід пояснює це тим, що сучасний тероризм - це часто заполітизоване явище, яке держави нині використовують у своїй геополітичній чи внутрішньополітичній грі. Крім того цей феномен динамічний, тобто постійно технологічно розвивається: з'являються нова зброя і методи маніфестацій, змінюються форми суспільної організації. В основі тероризму також лежить багатостороння концепція, що включає, окрім політичних, економічні, етнічні, релігійні й інші культурні аспекти ${ }^{2}$.

Проаналізувавши близько сотні дефініцій “тероризму” за авторства науковців 3 двадцяти країн світу, А. Шмід у 2011 р. доходить висновку, що у тлумаченні цього феномену потрібно враховувати щонайменше 12 компонентів (ще у 1988 р. А. Шмід та А. Йонмен виділяли 22 компоненти) 3 . 3 десяток характерних ознак використовує для поняття “тероризм” й український дослідник В. Ліпкан, хоча й пропонує тлумачити феномен за двома підходами - у широкому та вузькому значеннях ${ }^{4}$. Постають логічні питання: чи вивчають академічну літературу з терорології журналісти і чи можуть вони знати й враховувати всі ці численні компоненти під час висвітлення тематики? Результати опитувань студентів-журналістів дають негативну відповідь на обидва питання 5 .

Стереотипізації феномену тероризму сприяють історичні й культурні фактори, які ми можемо споглядати удефініціях українських тлумачних словників. Явище тероризму описується не нейтрально та не з огляду на природу феномену, а крізь призму історії України, зокрема вкладаючи конотати понять i подій державного терору, Білого i Червоного терорів. Таку історичну заангажованість можна помітити у фразах “класові супротивники", “фізичне знищення", “революційний рух”, “розправа ворожої армії” тощо. Накладання цього історичного контексту ще зі шкільних дисциплін формує в українця дещо викривлене розуміння природи тероризму, а оскільки навчальними програмами студентів-журналістів терорологія не передбачена, то таке стереотипне сприйняття феномену лишається в них і під час професійної діяльності.

\footnotetext{
${ }^{1}$ Поспелов, Б.В. (1976). Идеология «левого» радикализма в Японии и ее социально-классовая роль. Ежегодник «Япония», 1975, 111-120.

${ }^{2}$ Schmid, A. (2004). Terrorism: The Definitional Problem. Cleveland: Case Western Reserve School of Law.

${ }^{3}$ Schmid, A., Jongman, A. (1988). Political terrorism: A new guide to actors, authors, concepts, data bases, theories and literature. New Jersey.

4 Ліпкан, В.А. (2000). Тероризм і національна безпека Украӥни. Київ: Знання.

${ }^{5}$ Мисловський, І.В. (2019). Бачення теми тероризму студентами-журналістами: сприйняття, розуміння та причини феномену. Сучасні перспективи розвитку науки: матеріали III Міжнародної науково-практичної конференції (10-11 вересня 2019., м. Київ), 1, 48-50.
} 
Тут варто згадати i антитерористичну операцію на сході України (АТО), яка з самим феноменом тероризму навряд чи корелюється і $€$ насправді частиною гібридної війни Російської Федерації. Навіть в електронній енциклопедії "Вікіпедія" АТО тлумачиться як заходи проти "незаконних російських та проросійських збройних формувань у війні на сході України" та розпочата “через термінову потребу провести вибори президента і парламенту”, оскільки вони неможливі в умовах воєнного стану. Проте такі пояснення часто лишалися за кадром, а затягування АТО підсилювало наратив серед аудиторії і журналістів зокрема, що події на Донбасі можна називати тероризмом.

Більш влучним та наближеним до реальної природи явища $\epsilon$ тлумачення “тероризму" в українському законодавстві. Згідно із Законом України "Про боротьбу з тероризмом", тероризм це "суспільно небезпечна діяльність, яка полягає у свідомому, цілеспрямованому застосуванні насильства шляхом захоплення заручників, підпалів, убивств, тортур, залякування населення та органів влади або вчинення інших посягань на життя чи здоров'я ні в чому не винних людей або

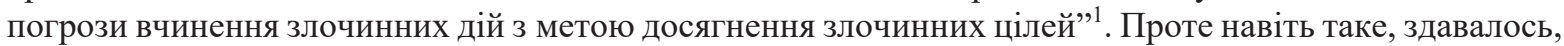
детальне визначення все ж таки лишає тонку межу, коли будь-який вид злочину можна назвати терористичним діянням, наприклад, неправильно встановивши мотиви й цілі злочинця, зманіпулювавши обставинами та детермінантами злочину чи навішуючи ярлик тероризму задля досягнення своїх політичних або інших цілей.

Таким чином ми підійшли до однієї з найголовніших детермінант стереотипного бачення тероризму - його політичної заангажованості. Політична природа феномену терористів позиціонує як опозицію до влади. Як відомо, у суспільстві завжди є частина людей, які незадоволені діями влади, а тому готові підтримувати опозиціонерів. Ріст суспільного невдоволення, прихована чи відкрита узурпація влади, безвихідь у мирному розв'язанні проблеми може підштовхнути громадян до більш радикальних поглядів, які у їхньому світосприйнятті частково зніматимуть відповідальність за незаконні методи боротьби опозиціонерів-терористів. Однак чи завжди ті, кого влада називає терористами, справді злочинці? Свого часу спеціальний доповідач ООН з прав людини К. Куфа добре змалював цю ситуацію в наступному висловлюванні: “для одного - терорист, для іншого - борець за свободу".

Такий дуалізм неодноразово у своїй професійній діяльності зустрічала міжнародний редактор "Радіо Свобода" О. Думська. За ії словами, готуючи матеріали про такі терористичні організації, як IPA, FARC, "Хезболла", часто зустрічала коментарі людей, які виправдовували незаконну діяльність терористів: захищали ідею незалежності, вбачали в них єдину дієву опозицію до влади, сприймали як месників тощо. О. Думська назвала це непростою ситуацією для журналістів, оскільки, з одного боку, такі журналістські принципи, як збалансованість та об'єктивність, не дозволяють ігнорувати коментарі інших сторін, а з іншого, рекламувати терористів та їхню доктрину заборонено всіма етичними кодексами журналістів. У такому випадку, на переконання редакторки, медійник повинен перевіряти, які організації Україна визнає як терористичні та керуватися цими даними у написанні матеріалів.

Юридичну неоднозначність статусу угруповань можна зустріти i на міжнародній арені. Нідерландський тероролог Е. Беккер пояснює це геополітикою та у приклади наводить угруповання "XАMAC". Ця політична організація, що переважно діє усекторі Газа та має легітимне представництво у законодавчому органі Палестинської держави, визнане терористичним в Ізраїлі, Канаді, США, Японії, Єгипті тощо, проте, наприклад, Норвегія, Швейцарія, Іран, Росія, Туреччина, Китай та інші країни не вважають членів "ХАМАСу” терористами.

Іспанський професор Х. Хордан розповів, що на півночі Іспанії досі $є$ громадяни, які толерують доктрині угруповання ЕTA (активна фаза дільності- друга половина 20 ст.), яке визнане терористичним та прагнуло незалежності регіону - так званої Країни Басків. Академік зауважує, що це пов'язано переважно із симпатіями людей до ідеї незалежності, а не до самих терористів. Однак навіть таке опосередковане виправдання цілей терористів на сторінках газет легітимізує їхню діяльність - якщо не перед законом, то в очах простих громадян, чого допускати теж не можна. За словами Х. Хордана, тамтешні іспанські регіональні ЗМІ опосередковано пропагували наміри терористів ЕТА, як-от здобуття незалежності Країни Басків, ігноруючи легальність методів боротьби.

\footnotetext{
1 Закон про боротьбу з тероризмом 2003 (Верховна Рада України). Офіиійний сайт Верховної Ради Украйни. $<$ https://zakon.rada.gov.ua/laws/show/638-15/ed20181104> (2020, лютий, 20).
} 
На його думку, проявляючи лояльність до цілей терористів та без крайнього осуду висвітлюючи їхню діяльність, журналісти самі стають співучасниками та деструктивно впливають на суспільство.

Ненавмисне та опосередковане виправдання діяльності терористів шляхом зображення народної підтримки можна пояснити тим, що журналісти не бачать принципової різниці між тероризмом та використанням форм насильства у національно-визвольній боротьбі. Львівські дослідники детально проаналізували цей аспект та дійшли висновку, що, визначаючи вид діяльності, потрібно звертати увагу на ії суть (терористи більше погрожують насильством, а національні борці діють, використовуючи різні методи), мету (винятково національно-визвольна боротьба, а не проста зміна політичного режиму) і жертв (від рук терористів переважно страждає цивільне населення) ${ }^{1}$.

Політична заангажованість тероризму проявляється i в редакційній політиці багатьох міжнародних 3МІ. Міжнародний редактор телеканалу “Прямий” Д. Матвіїв розповіла, що іноземні медіа по-різному висвітлюють діяльність терористичних організацій, зважаючи на свої ідеологічні переконання та геополітичні преференції. Наприклад, часті напади в Срусалимі за участю палестинців ізраїльські видання чи не відразу називають терактами. Водночас медіа сусідніх мусульманських країн, які мають далеко не найкращі дипломатичні відносини з Ізраїлем, можуть звинувачувати у провокаціях ізраїльську поліцію та владу, виправдовуючи дії терориста. При цьому, що найцікавіше, таке виправдовування відбувається не з волі державного регулятора, а з ініціативи самого видання чи окремого журналіста.

На формування однобокого (вважай стереотипного, оскільки використовується спрощена модель феномену) бачення терористичної ситуації у цьому випадку слугують особистісні погляди журналіста: релігійна приналежність (наприклад, співчуття до вірянина з близької конфесії), національне виховання (як-от недопущення сепаратистських рухів), ідеологія (лояльність до доктрин, ідеї яких лежать у площині власного світосприйняття), державна зовнішня політика (підтримка союзників у боротьбі 3 тероризмом чи поблажливе ставлення до терористів, які діють проти країни-ворога).

Теорія фреймування, представлена соціологом Е. Гофманом у 1974 р., може слугувати ще одним поясненням стереотипного сприйняття тематики тероризму. Журналісти у своєму виробничому процесі часто обмежені комерційним запитом аудиторії, продукуючи матеріали відповідно до бажань, смаків та інформаційної компетенції їхнього споживача. Останнє й змушує медійників застосовувати для тематики тероризму, складність якої була обгрунтована вище, схеми інтерпретацій, певне обрамлення чи ярликування, користуючись первинними стереотипами або рамками (фреймами як персоналізованими структурами даних, що описують фрагмент знань про світ чи ситуацію). Т. Гітлін зазначає, що медіафреймування вже стало робочим планом для медійників, що дозволяє досить швидко й успішно ідентифікувати та представити інформацію аудиторії.

Однак згодом і сам журналіст потрапляє у пастку фреймування, зосереджуючи свою та увагу аудиторії лише на сенсаційні факти новини (переважно про жертви, метод та обставини злочину, сенситивні образи і деталі, міграційні чи релігійні обумовленості тощо), а не всеосяжно висвітлюючи можливі політичні причини та мотиви терористичної діяльності. Відтак американський дослідник у галузі соціальних комунікацій Д. Шойфеле одним з чотирьох концептів медіафреймування назвав вплив фрейму на індивідуальному рівні ${ }^{3}$. Це стається за умови, коли ціннісні, когнітивні та біхевіористські акценти журналіста зміщуються не на глибинне розуміння та інтерпретування реальності, а на заданий медійний порядок денний. Це, як у своєму дослідженні зазначає Б. МакНейр, переважно емоційні та шокуючі елементи теракту, як сам вибух чи терорист, котрий розмахує та погрожує зброєю. Водночас такі основоположні елементи, як історичний бекграунд чи політичний контекст події, журналістами опускаються ${ }^{4}$.

Такий фреймований вид подачі інформації про тероризм формуватиме у журналістів викривлене бачення феномену та його головних акторів. М. Келлі та Т. Мітчелл зауважують, що без детального розуміння подій (перш за все, політичного, історичного та культурного бекграундів)

\footnotetext{
${ }^{1}$ Саміло, А.В., Шишко, В.В. (ред.) (2005). Тероризм у формі боротьби за національний суверенітет:

до постановки проблеми. Вісник Національного університету "Львівська політехніка". Юридичні науки, 824, 313-319.

${ }^{2}$ Gitlin, T. (1984). The whole world is watching: Mass media in the making and unmaking of the new left. Berkley, CA: University of California Press.

${ }^{3}$ Scheufele, D.A. (1999). Framing as a theory of media effects. Journal of Communication, 1(49), 103-132.

${ }^{4}$ McNair, B. (2003). An introduction to political communication. London: Routledge.
} 
медійники бачитимуть в терористах винятково “психопатів"”. Тому ознайомлення з бодай основними цілями різних терористичних організацій обов' язкове для розуміння діяльності цих угруповань, їхніх окремих членів чи “натхненників". Це також допоможе спрогнозувати подальші дії терористів та осягнути їхній вплив на геополітичній мапі світу.

Стереотипізація феномену в журналістському середовищі обумовлюється ще й такими виробничими обмеженнями, як швидкість, простір і час. У епоху інтернету, новітніх медіа та соціальних мереж традиційним ЗМК доводиться нехтувати якістю та глибиною матеріалу, аби встигати з подачею актуальної новинної інформації. До того ж досі лишаються часові рамки для матеріалів. Наприклад, на радіо ліміт для новини становитиме хвилину-півтори, на телебаченні репортаж навряд чи триватиме понад три хвилини (зауважимо, що значна частина матеріалу наповнюватиметься аудіовізуальними елементами події у вигляді “лайфів”), а в газетах у разі не дуже резонансного теракту редактори швидше обмежаться невеликою заміткою.

Така тенденція пояснюється низьким інтересом української аудиторії не лише до теми міжнародного тероризму, а й загалом до подій у світі. За результатами опитування Фонду “Демократичні ініціативи”, 51\% українців не зміг назвати головної політичної події 2019 року у світі ${ }^{2}$. Майже кожний четвертий громадянин (23\%) такою подією вважає паризький саміт нормандської четвірки, що свідчить про упереджене сприйняття геополітичної карти та перебільшену україноцентричність світу. Ще 6\% головною політичною подією світу попереднього року назвали процес імпічменту президента США Дональда Трампа, в якому Україна також пасивно брала участь, а тому подія широко висвітлювалася в загальнонаціональних медіа. I лише по $2 \%$ українців визначили головною міжнародною подією французькі протести “жовтих жилетів”, Brexit та війну в Сирії.

Однак менший попит на міжнародну інформацію можна назвати світовим трендом, який бере свій початок ще з кінця 20 ст. Наприклад, з 1988 р. по 2010 р. кількість міжнародних новин на американських телеканалах NBC, ABC і CBS зменшилася на 56\%. Схожа ситуація за той же період склалася і з друкованими ЗМІ - кількісна присутність закордонних новин впала з 27\% до 11\% (а під

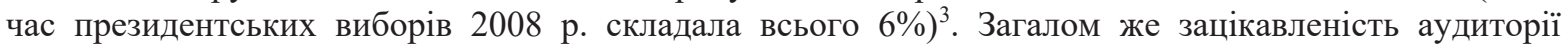
до міжнародної інформації значно менша, ніж до національної чи місцевої. Дослідники з Реw Research Center, опитавши громадян 38 країн, встановили попит на новини світу в різних регіонах: така інформація цікавить $68 \%$ американців, $65 \%$ европейців, $58 \%$ африканців, 56\% представників Азійсько-Тихоокеанського регіону, $51 \%$ вихідців із Близького Сходу та $35 \%$ латиноамериканців ${ }^{4}$. Варто зазначити, що дані є швидше наочними з огляду щонайменше на два фактори - відносну репрезентативність (технологічні, політичні і культурні відмінності держав світу, які брали участь в опитуванні) та поняття зацікавленості (кліпове споживання новин чи глибинне відстежування події), - однак вони дозволяють констатувати наявність такого світового тренду.

Прямий наслідок цього тренду - врізання фінансування напрямку міжнародної журналістики в редакціях, а відтак закриття закордонних корпунктів та зменшення кількості фахових журналістів. Лише протягом 2000-х рр. кількість міжнародних кореспондентів в десяти найбільших газетах США скоротилася вчетверо, а американська телемережа кореспондентів за останні десятиліття закрила більшу частину закордонних бюро 5 . Щодо українських закордонних корпунктів, то їхнє представлення завжди було обмежене столицями провідних західних держав (переважно США, Німеччина, Бельгія, Франція; жодних власних бюро на Близькому Сході), а нині вони закриваються

\footnotetext{
${ }^{1}$ Kelly, M.J., Mitchell, T.H. (1981). Transnational terrorism and the Western elite press. Political Communication, 1(3), 269-296.

2 Більшість українців не змогли назвати жодної важливої політичної події світу за 2019 рік. Інформаційне агентство УНН. <https://www.unn.com.ua/uk/news/1843508-bilshist-ukrayintsiv-ne-zmogli-nazvati-zhodnoyivazhlivoyi-politichnoyi-podiyi-svitu-za-2019-rik> (2020, лютий, 24).

${ }^{3}$ Willnat, L., Martin, J. (2012). Foreign correspondents-An endangered species? The global journalist: In the 21st century. New York: Routledge, 495-510.

${ }^{4}$ Mitchell, A., Simmons, K., (ed). (2018). Publics Globally Want Unbiased News Coverage, but Are Divided on Whether Their News Media Deliver. Pew Research Center.

$<$ https://www.pewresearch.org/global/2018/01/11/publics-globally-want-unbiased-news-coverage-but-are-divided-onwhether-their-news-media-deliver $>$ (2020, лютий, 25).

${ }^{5}$ Willnat, L., Martin, J. (2012). Foreign correspondents-An endangered species? The global journalist: In the 21st century. New York: Routledge, 495-510.
} 
чи недофінансовуються. В. Б’єрнацкі зауважує, що недостатнє ознайомлення журналіста 3 місцевими подіями та загалом культури (тобто не перебуваючи на місці подій) робить його вразливим до стереотипів ${ }^{1}$.

Зважаючи на брак фахових кадрів, фінансових ресурсів, фрагментарність спеціалізованих знань та низький попит аудиторії, висвітлення тероризму відбувається кліпово та мозаїчно. У попередніх дослідженнях нами було встановлено, що журналісти переважно подають інформацію про саму подію - терористичний акт - i пропорційно не зосереджують свою увагу на подальшому розслідуванні цього теракту, загалом боротьбі з тероризмом чи суспільній єдності проти такого виклику ${ }^{2}$. Таке висвітлення терористичної діяльності без контртерористичних заходів може вплинути на сприйняття тероризму як феномену успішного, непоборного, безкарного, політично невмотивованого, хаотичного чи непропорційно загрозливого.

Остання ознака поступово вкорінюється у сприйнятті журналістів через непропорційне висвітлення тероризму щодо кількості його жертв та геополітичного вектора. Йдеться про те, що терористичні акти настільки часто й широко висвітлюються без розуміння загальної статистики смертності, що складається враження навіть у медійників, ніби це одна із головних причин смерті людей, що геть не відповідає реальності. Наприклад, у 2016 році у США тероризм спричинив менше 0,01\% смертності ${ }^{3}$. Журналісти, проаналізувавши дані початку другого десятиліття 20 ст., підрахували, що американець має у понад чотири з половиною тисяч разів більше шансів померти від алкоголізму, ніж від рук терориста, а лікарська помилка та ожиріння стають причиною смерті в майже шість тисяч разів частіше, ніж тероризм ${ }^{4}$. Та попри це хвороби і кримінал, які найчастіше спричиняли смерть, висвітлюються в медіа значно менше, ніж тероризм: видання "The Guardian" i "The New York Times" третину всього свого контенту щодо смертей людей присвячують саме тероризму 5 .

Непропорційність у висвітленні тероризму присутня не лише кількісна, але й геополітична. Йдеться про стереотипне уявлення про тероризм як суто антизахідної діяльності. Таке хибне сприйняття пояснюється надмірною увагою найпопулярніших світових медіа до терактів на Заході та порівняно побіжним висвітленням тероризму в інших регіонах, як-от на Близькому Сході чи у Північній Африці, де від рук терористів гине найбільше людей.

У попередніх дослідженнях ми встановили таку непропорційність i на українських інформаційних телеканалах. Наприклад, під час моніторингу новин на телеканалі “NewsOne” сумарно теракти у Свропі висвітлювалися у шість разів більше попри те, що жертв на Близькому Сході було більше майже у п'ять разів. За підрахунками, на одного загиблого на Близькому Сході припадало до 2 секунд ефірного часу (за період моніторингу матеріали про 4 теракти зі 115 загиблими на Близькому Сході зайняли 3 хвилини 45 секунд ефірного часу), а от на одну жертву в європейських терактах - 57,5 секунд (3 теракти 323 жертвами у Європі - 22 хвилини 2 секунди). Схожі дані отримано після перегляду телеканалу “112 Україна": ефірний час на одну жертву близькосхідного теракту не перевищував 4 секунди (3 теракти з 81 загиблим на Близькому Сході - 5 хвилин 19 секунд), а на загиблого у Європі відводилося 54,5 секунди (4 теракти 323 жертвами у Європі - 20 хвилин 54 секунди $)^{6}$.

Не маючи базових знань з терорології, журналісти на основі такої непропорційності конструюють власну нову реальність, у якій відсутність інформації і статистичних даних стають міцним підгрунтям для стереотипів. Наприклад, медійники нині тісно пов'язують тероризм з мусульманами, оскільки їхня журналістська діяльність справді припала на спалах релігійного тероризму. Вчені підрахували, що топові американські медіа висвітлюватимуть терористичний акт

\footnotetext{
${ }^{1}$ Biernatzki, W.E. (2002). Terrorism and mass media. Communication Research Trends, 21(1), 1-27.

${ }^{2}$ Мисловський, I.В. (2017). Типологічні особливості новин про тероризм на українському телебаченні (на прикладі "NewsOne" та "112 Україна"). Наукові записки Інституту журналістики, 2, 70-76.

${ }^{3}$ Shen, O. Charting Death: Reality vs Reported. <https://owenshen24.github.io/charting-death> (2020, лютий, 26).

${ }^{4}$ You're More Likely to Be Killed By Brain-Eating Parasites, Texting While Driving, Toddlers, Lightning, Falling Out of Bed. Zero Hedge. <https://www.zerohedge.com/news/2014-07-24/you're-more-likely-be-killed-brain-eatingparasites-texting-while-driving-toddlers-1> (2020, лютий, 26).

${ }^{5}$ Shen, O. Charting Death: Reality vs Reported. <https://owenshen24.github.io/charting-death> (2020, лютий, 26).

${ }^{6}$ Мисловський, I.B. (2017). Тема тероризму в новинах на українських телеканалах (на прикладі “NewsOne” ma “112 Україна"): наукова робота на здобуття кваліфікації магістра. Київ: Інститут журналістики.
} 
на $758 \%$ більше, якщо його виконавцем буде мусульманин ${ }^{1}$. Однак тут варто відразу зауважити, що Коран обмежує та застерігає від агресії вірян, навіть у випадках коли іії використовують вороги ісламу. Також опитування громадської думки свідчать про те, що абсолютна більшість населення мусульманських країн категорично проти нападів терористів на мирне населення, а теракти вважають діяннями, що суперечать ісламу і не можуть мати виправдання² .

Аби зберегти баланс у теоретико-практичній площині досліджуваного питання (коли про предмет наукового пізнання висловлюються не лише науковці, а й представники професії), ми провели соціологічне опитування. Опитування мало форму одиничного, стандартизованого, фокусованого веб-анкетування та було експертним (у ньому брали участь винятково міжнародні редактори різних українських медіа). Кількість респондентів- 31. Оскільки опитування було фокусованим, тобто спрямоване на вивчення вузького тематичного предмета, анкета містила три питання: “Досвід роботи у журналістиці”, “Чи вважаєте Ви, що українські журналісти мають певні стереотипи щодо феномену тероризму?”, “На вашу думку, які три головні фактори можуть обумовлювати стереотипне бачення феномену тероризму в журналістському середовищі?”.

Питання про досвід важливе для репрезентації результатів з огляду на те, що більш досвідчені журналісти можуть проаналізувати виробничу сферу за довший період часу, а міжнародні редактори як респонденти мають можливість порівняти професійність колег з інших відділів щодо висвітлення тероризму. За результатами відповідей, $76 \%$ опитаних міжнародних редакторів працюють у сфері журналістики більше 3 років, 19\% - 1-3 роки, а 5\% - менше одного.

Перед відкритим третім питанням щодо детермінант стереотипного бачення, важливо було поставити контрольне питання, чи загалом журналісти визнають досліджувану проблему. I, за результатами анкет, $85 \%$ опитаних редакторів схиляються до того, що стереотипи про тероризм у журналістському середовищі наявні (33\% респондентів відповіли “так”, 52\% - “швидше так”). Жоден міжнародний редактор не дав ствердної негативної відповіді (“ні”), а $15 \%$ обрали варіант “швидше ні”.

У третьому питанні респондентам пропонувалося назвати три головні фактори, які обумовлюють формування викривленого уявлення про тероризм у журналістів. Варіанти відповідей та їхня кількісна присутність серед усіх опрацьованих анкет представлені у вигляді діаграми (див. рис. 1).

Найбільш згадуваними детермінантами виявилися "стереотипне висвітлення тематики тероризму в першоджерелах" та “неосвіченість журналістів" - ці фактори згадував кожний другий респондент. На думку міжнародних редакторів, викривлене бачення феномену, перш за все, формується через джерела інформації, якими послуговуються українські журналісти. Оскільки вони самі не присутні на терористичних подіях, доводиться користуватися матеріалами інших 3МI, в яких, на думку респондентів, і міститься стереотипне зображення терористичної ситуації. А от брак власних знань про різні угруповання та їхню насильницьку політичну боротьбу робить медійників вразливих до хибних інтерпретацій інших журналістів чи ЗМІ.

Майже кожний третій опитаний вважає, що індивідуальна упередженість журналіста, яка проявляється у його релігійних, національних, політичних, ідеологічних поглядах, є причиною заангажованого бачення тероризму.

Кожний четвертий респондент до детермінант зарахував брак фахових кадрів, що принципово відрізняється від фактора неосвіченості. Тут йдеться про відсутність вузькоспеціалізованих редакторів-терорологів на українському медіаринку, які б могли слугувати надійним джерелом інформації для інших колег.

Інші детермінанти в анкетах з'являлися від 1 до 3 разів (далі перераховано у порядку спадання кількості згадувань): оперативність новини замість якості, надмірна політизація явища, складність у тлумаченні феномену, медіафреймування, виступи політиків, фільми, незацікавленість журналіста до тематики, вплив оточення, соціальні ярлики, невпорядкованість журналістських стандартів, комерційні інтереси ЗМІ, війна на Донбасі з ярликом тероризму, спрощений дуалістичний поділ явища на “добро-зло”.

\footnotetext{
${ }^{1}$ Ritchie, H., Hasell, J., Appel, C., Roser, M. Terrorism. Our World in Data. <https://ourworldindata.org/terrorism> (2020, лютий, 28).

${ }^{2}$ Kull, S. The American Public on the Islamic World. World Public Opinion. <http://worldpublicopinion.net/ the-american-public-on-the-islamic-world $>$ (2020, лютий, 28$)$.
} 


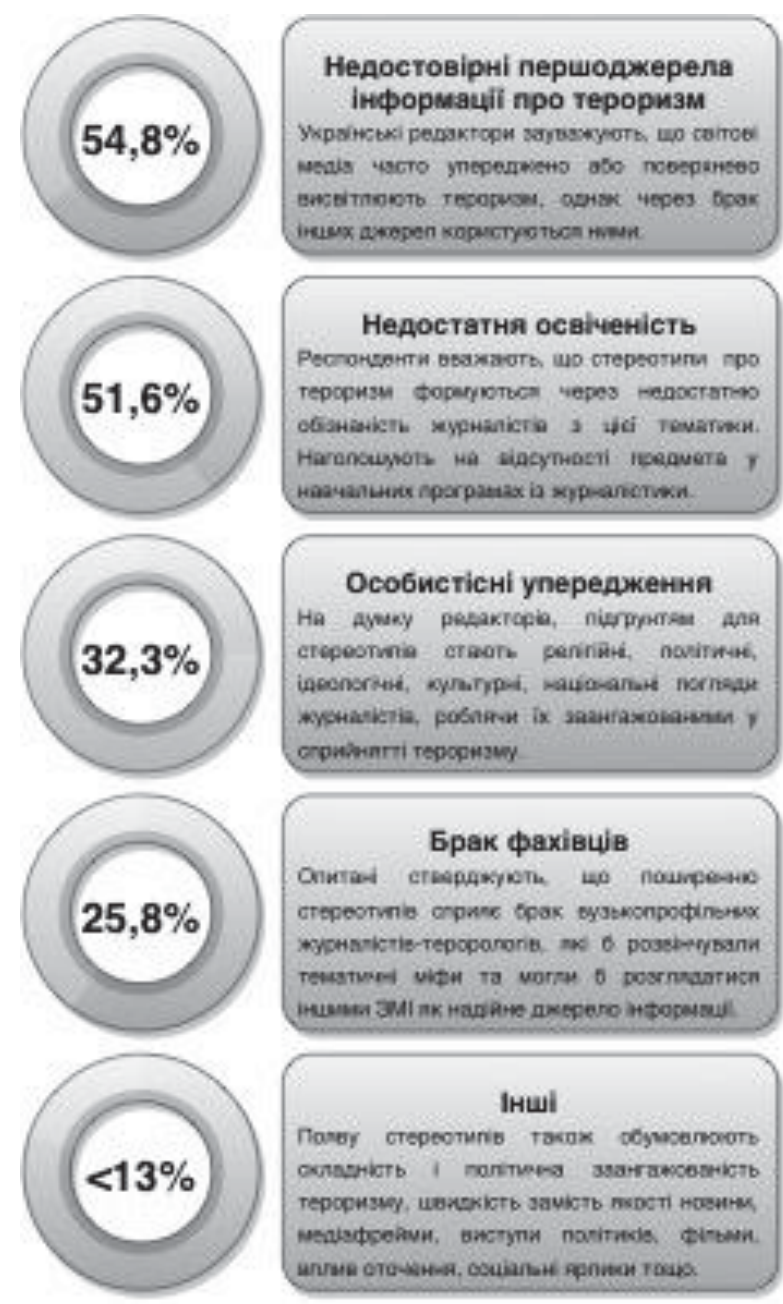

Рас. 1. Чаетога згадувань, аетермінант украйнськыми мікнаредними ре,дакторами

Загалом усі описані у статті детермінанти стереотипізації феномену тероризму у журналістському середовищі можна умовно поділити на чотири типи (див. рис. 2):

1. індивідуальні- особистісне сприйняття та інтерпретування явища, яке виходить зі світогляду, освітніх здобутків, критичного мислення (наприклад, брак тематичних знань, усі види упереджень, суб’єктивність в оцінці діяльності терористів, підтримка сторін конфлікту тощо);

2. суспільні - вплив суспільства на бачення тероризму індивідом (як-от нав'язування соціальних норм, навішування ярликів, переконання авторитетами, влада більшості і т.д.);

3. виробничі - встановлені правила і практики професійної діяльності у висвітленні тероризму, продиктовані комерційними інтересами ЗМI, медіатенденціями та запитом аудиторії (приміром, медійний порядок денний, фреймування, сенсаційність, шок-контент, ігнорування мотивів на користь висвітлення наслідків атаки, брак фахових кадрів у медіасфері та інші);

4. предметні - природна й історична складність феномену тероризму (наприклад, відсутність визнаної на міжнародному рівні єдиної дефініції, різні підходи до тлумачення явища, політична заангажованість тероризму тощо).

Хочемо зауважити, що точно виміряти чи спрогнозувати влив окремої детермінанти чи навіть цілого типу на формування стереотипного бачення тероризму в журналіста нам видається завданням складним з огляду на продукування релевантних і валідних результатів, оскільки припускаємо, що набір детермінант та їхнє ранжування за показником впливовості для кожного журналіста будуть індивідуальними. А тому розв'язання проблеми - усунення детермінант - має відбуватися комплексно. 


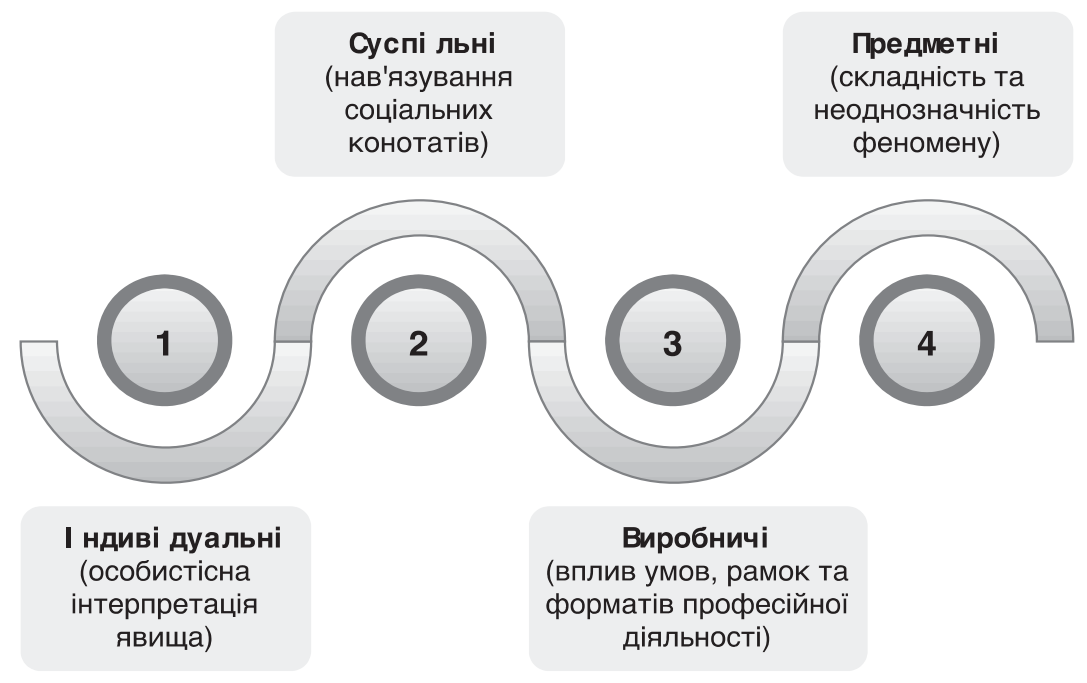

Рис. 2. Типологія детермінант стереотипізації феномену тероризму

Проте розроблена типологія допомагає окреслити ті сфери, які потребують найбільшої уваги з огляду на кількісно-якісну присутність детермінант. Останнє ми вирахували за допомогою нашого опитування міжнародних редакторів: встановили, до якого типу відносяться усі згадані детермінанти в анкетах, та підрахували загальну кількість для кожного типу (див. рис. 3).

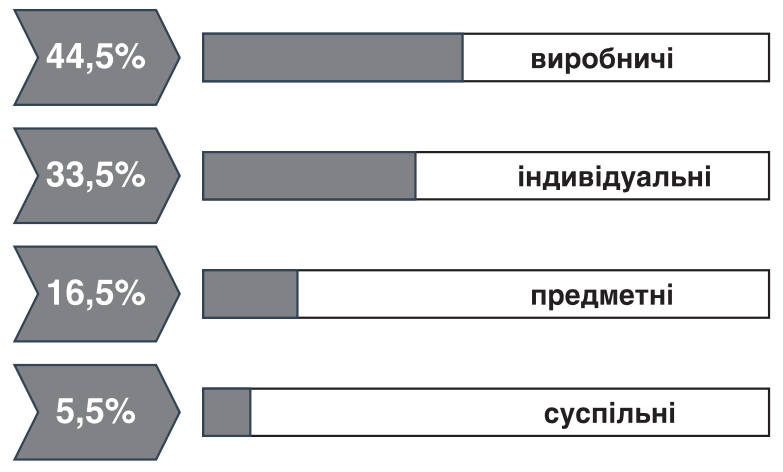

Рис. 3. Кількісне співвідношення названих в анкетах детермінант за їхнім типом

Найчастіше респонденти згадували виробничі (44,5\% від усіх відповідей) та індивідуальні детермінанти $(33,5 \%)$, тобто стереотипне бачення феномену тероризму у журналістському середовищі, на їхню думку, обумовлені роботою ЗМІ та особистим світоглядом (індивідуальною інтерпретацією об'єктів дійсності). А от складність феномену (предметні) та соціальний вплив (суспільні) не так часто опитані зараховували до головних детермінант - $16,5 \%$ та 5,5\% відповідно.

Висновки. Стереотипізація феномену тероризму в журналістському середовищі обумовлюється численними факторами, які сумарно продукують хибний образ терористичної ситуації у світі. До потенційних детермінант ми зарахували такі: відсутність знань з терорології та неповне розуміння геополітичної мапи світу; природна складність феномену і його політична заангажованість; різночитання поняття “тероризм” та його історично-юридична розмитість; відсутність близьких до тематики тероризму предметів в університетських освітніх програмах для журналістів; упередження журналіста, пов'язані з його особистими релігійними, національними, політичними, культурними та ідеологічними поглядами; медійний порядок денний та медіафреймування; закриття іноземних корпунктів i зменшення фінансування міжнародної журналістики; непрофесійне і непропорційне висвітлення тематики тероризму в медіа, які служать 
першоджерелами для інших 3MI; універсальний журналізм та брак редакторів-терорологів на медіаринку; комерціалізація ЗМІ та потяг до сенсаційності; кліпове мислення та перевага оперативності подачі інформації над іiї якістю.

Переважна більшість журналістів погоджується, що професійне середовище має стереотипи про тероризм. Головними факторами вони називають необ'єктивну (упереджену, стереотипну чи хибну) інформацію в першоджерелах (інших ЗМI), неосвіченість журналістів, їхні особисті світоглядні упередження та відсутність вузькоспеціалізованих фахових кадрів у журналістському середовищі.

Проаналізовані у статті детермінанти можна поділити на чотири типи: індивідуальні, суспільні, виробничі та предметні. Журналісти вважають, що найчастіше стереотипізація феномену тероризму відбувається через виробничі та індивідуальні детермінанти. Таким чином для ефективного розв'язання проблеми варто зосередити увагу на усуненні найбільш типових факторів.

\section{References:}

1. Tsyganov, V.V. (2004). Media-terrorizm. Terrorizm i sredstva massovoj informacii [Media terrorism. Terrorism and means of mass information]. Kyiv: Nika-Centr. [in Russian].

2. Myslovskyi, I.V. (2019). Bachennia temy teroryzmu studentamy-zhurnalistamy: spryiniattia, rozuminnia ta prychyny fenomenu [Vision of the topic of terrorism by journalistic students: perception, understanding and causes of the phenomenon]. Suchasni perspektyvy rozvytku nauky: materialy III Mizhnarodnoi naukovo-praktychnoi konferentsii (10-11 veresnia 2019., m. Kyiv) [Contemporary prospects for the development of science: materials of the Third International Scientific and Practical Conference (September 10-11, 2019, Kyiv)]. [in Ukrainian].

3. Myslovskyi, I. V. (2019). Mizhkulturna komunikatsiia u vysvitlenni teroryzmu: stereotypne bachennia fenomenu ukrainskymy zhurnalistamy [Intercultural communication in the coverage of terrorism: stereotypical view of the phenomenon by Ukrainian journalists.]. Sotsialni komunikatsii: fundamentalni paradyhmy rozvytku: materialy Mizhnarodnoi naukovo-praktychnoi konferentsii (4-5 zhovtnia 2019 r., m. Kyiv) [Social communications: fundamental development paradigms: materials of the International Scientific and Practical Conference (October 4-5, 2019, Kyiv)]. [in Ukrainian].

4. Myslovskyi, I. V. (2017). Ryzyky ta naslidky neprofesiinoi diialnosti zhurnalistiv u vysvitlenni temy teroryzmu. Strakhoheneruvalnyi potentsial novyn [Risks and consequences of unprofessional activities of journalists in covering the topic of terrorism. News fear generating potential]. Mediakontent: vydy, formy podachi ta osoblyvosti spryiniattia: materialy Vseukrainskoi naukovo-praktychnoi konferentsii (4 kvitnia 2017 r., m. Kyiv) [Media content: types, forms of submission and rerceptual features: materials of the Ukrainian Scientific and Practical Conference (April 4, 2017, Kyiv)]. [in Ukrainian].

5. Deivis, N. (2011). Novyny plaskoi Zemli [Flat Earth News]. Kyiv: Tempora. [in Ukrainian].

6. Teilor, P. (2014). Rozmovy z terorystamy. Moia podorozh vid IRA do Al-Kaidy [Talking to Terrorists. A Personal Journey from the IRA to Al Qaeda]. Kyiv: Tempora. [in Ukrainian].

7. Pospelov, B.V. (1976). Ideologiya «levogo» radikalizma v Yaponii i ee social'no-klassovaya rol' [The ideology of "left" radicalism in Japan and its social-class role]. Ezhegodnik «Yaponiya» [Annual journal 'Japan']. [in Russian].

8. Schmid, A. (2004). Terrorism: The Definitional Problem. Cleveland: Case Western Reserve School of Law. [in English].

9. Schmid, A., Jongman, A. (1988). Political terrorism: A new guide to actors, authors, concepts, data bases, theories and literature. New Jersey. [in English].

10. Lipkan, V.A. (2000). Teroryzm i natsionalna bezpeka Ukrainy [Terrorism and national security of Ukraine]. Kyiv: Znannia. [in Ukrainian].

11. Zakon Ukrainy "Pro borot'bu z teroryzmom". 2003 (Verkhovna Rada Ukrainy) [Law on the Fight against Terrorism 2003 (Verkhovna Rada of Ukraine)]. Ofitsiinyi sait Verkhovnoi Rady Ukrainy [The official website of the Verkhovna Rada of Ukraine]. <https://zakon.rada.gov.ua/laws/show/638-15/ed20181104> [in Ukrainian]. (February 20, 2020).

12. Samilo, A. V., Shyshko, V. V. (ed.) (2005). Teroryzm u formi borotby za natsionalnyi suverenitet: do postanovky problemy [Terrorism in the struggle for national sovereignty: before the problem is posed]. Visnyk Natsionalnoho universytetu "Lvivska politekhnika". Yurydychni nauky [Visnyk of National University 'Lvivska politekhnika'. Law], no. 824, 313-319. [in Ukrainian].

13. Gitlin, T. (1984). The whole world is watching: Mass media in the making and unmaking of the new left. Berkley, CA: University of California Press. [in English].

14. Scheufele, D.A. (1999). Framing as a theory of media effects. Journal of Communication, 1(49), 103-132. [in English].

15. McNair, B. (2003). An introduction to political communication. London: Routledge. [in English].

16. Kelly, M. J., \& Mitchell, T. H. (1981). Transnational terrorism and the Western elite press. Political Communication, 1(3), 269-296. [in English]. 
17. Bilshist' ukraintsiv ne zmohly nazvaty zhodnoi vazhlyvoi politychnoi podii svitu za 2019 rik [Most Ukrainians have not been able to name a single major political event in the world for 2019]. Informatsiine ahentstvo 'UNN' [News agency 'UNN']. <https://www.unn.com.ua/uk/news/1843508-bilshist-ukrayintsiv-ne-zmogli-nazvatizhodnoyi-vazhlivoyi-politichnoyi-podiyi-svitu-za-2019-rik> [in Ukrainian]. (February 24, 2020).

18. Willnat, L., Martin, J. (2012). Foreign correspondents-An endangered species? The global journalist: In the 21st century (pp. 495-510). New York: Routledge. [in English].

19. Mitchell, A., Simmons, K., (ed). Publics Globally Want Unbiased News Coverage, but Are Divided on Whether Their News Media Deliver. Pew Research Center. <https://www.pewresearch.org/global/2018/01/11/publicsglobally-want-unbiased-news-coverage-but-are-divided-on-whether-their-news-media-deliver $>$ [in English]. (February 25, 2020).

20. Biernatzki, W. E. (2002). Terrorism and mass media. Communication Research Trends, 21(1), 1-27. [in English].

21. Myslovskyi, I. V. (2017). Typolohichni osoblyvosti novyn pro teroryzm na ukrainskomu telebachenni (na prykladi "NewsOne" ta "112 Ukraina") [Typological Peculiarities of News about Terrorism on Ukrainian Television ("NewsOne" and "112 Ukraine" Information Channels)]. Naukovi zapysky Instytutu zhurnalistyky [Scientific notes of Institute of Journalism], 2, 70-76. [in Ukrainian].

22. Shen O. Charting Death: Reality vs Reported. <https://owenshen24.github.io/charting-death> [in English]. (February 26, 2020).

23. You're More Likely to Be Killed By Brain-Eating Parasites, Texting While Driving, Toddlers, Lightning, Falling Out of Bed. Zero Hedge. <https:/www.zerohedge.com/news/2014-07-24/you're-more-likely-be-killed-braineating-parasites-texting-while-driving-toddlers-l $>$ [in English]. (February 26, 2020).

24. Myslovskyi, I. V. (2017). Tema teroryzmu v novynakh na ukrainskykh telekanalakh (na prykladi "NewsOne" ta "112 Ukraina"): naukova robota na zdobuttia kvalifikatsii mahistra [Covering of terrorism in news on Ukrainian TV channels "NewsOne" and "112 Ukraine": the thesis for attaining master's degree]. Kyiv: Institute of Journalism.

25. Ritchie, H., Hasell, J., Appel, C., Roser, M. Terrorism. Our World in Data. <https://ourworldindata.org/terrorism> [in English]. (February 28, 2020).

26. Kull, S. The American Public on the Islamic World. World Public Opinion. <http://worldpublicopinion.net/ the-american-public-on-the-islamic-world $>$ [in English]. (February 28, 2020). 